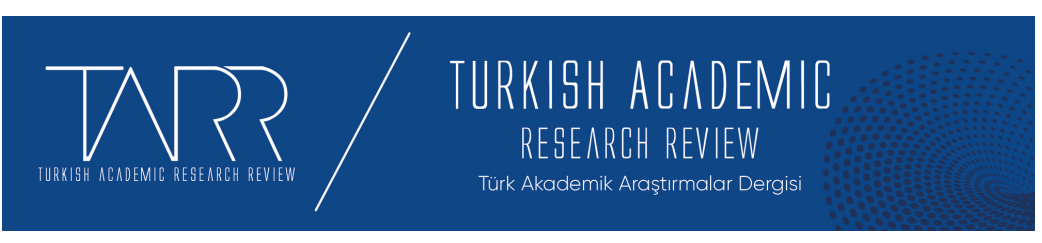

e-ISSN: 2602-2923 Yil/Year: $2021 \quad$ Cilt/Volume: 6 Sayı/Issue: 3

\title{
Baba Rahîm Meşreb Menâkıb-nâmesi'nde Geçen Şiirlerdeki Acem Kaynaklı Mitolojik Şahıslar
}

\author{
Mythological Characters of Persian Origin in the Poems in Baba \\ Rahim Mashrab Manaqibnama
}

\section{İbrahim AKÇA}

Arş. Gör. Dr., Harran Üniversitesi, İlahiyat Fakültesi, Türk İslam Edebiyatı Bölümü / Harran University, Faculty of Theology, Turkish Islamic Literature Department, ibrahimakca@harran.edu.tr, Orcid ID: 0000-0002-4922-9047

\begin{tabular}{r|l} 
Makale Bilgisi & Article Information \\
Makale Türü - Article Type & Araştırma Makalesi / Research Article \\
Geliş Tarihi - Date Received & 5 Ağustos / August 2021 \\
Kabul Tarihi - Date Accepted & 16 Eylül / September 2021 \\
Yayın Tarihi - Date Published & 20 Eylül / September 2021 \\
Yayın Sezonu & Temmuz - Ağustos - Eylül \\
Pub Date Season & July - August - September
\end{tabular}

Atıf / Cite as: Akça, İ. (2021), Baba Rahîm Meşreb Menâkıb-nâmesi'nde Geçen Şiirlerdeki Acem Kaynaklı Mitolojik Şahıslar/ Mythological Characters of Persian Origin in the Poems in Baba Rahim Mashrab Manaqibnama. Turkish Academic Research Review, 6 (3), 935-954. Retrieved from https://dergipark.org.tr/tr/pub/tarr/issue/64962/979178

Intihal / Plagiarism: Bu makale, en az iki hakem tarafindan incelenmiş ve intihal içermediği teyit edilmiştir. / This article has been reviewed by at least two referees and confirmed to include no plagiarism. https://dergipark.org.tr/tr/pub/tarr

Copyright (C) Published by Mehmet ŞAHIN Since 2016- Akdeniz University, Faculty of Theology, Antalya, 07058 Turkey. All rights reserved.

Turkish Academic Research Review - Türk Akademik Araştırmalar Dergisi 


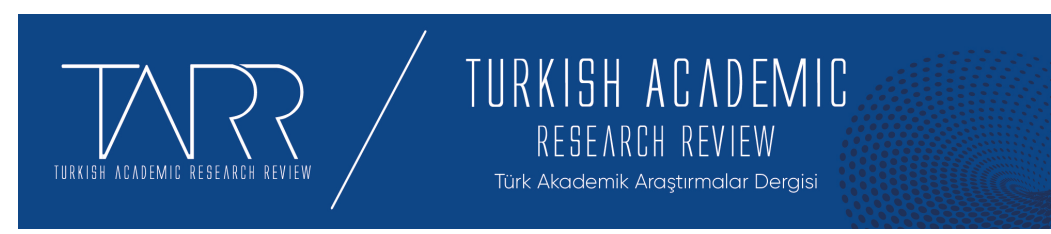

e-ISSN: 2602-2923 Yll/Year: $2021 \quad$ Cilt/Volume: 6 Sayı/Issue: 3

\title{
Baba Rahîm Meşreb Menâkıb-nâmesi'nde Geçen Şiirlerdeki Acem Kaynaklı Mitolojik Şahıslar
}

\author{
İbrahim AKÇA
}

\section{$\ddot{O} z$}

Baba Rahîm Meşreb, Çağatay Türkçesinin Klasik Sonrası Döneminde (M. 16001921) yaşamış sûfî şairlerden biridir. Türkistan sahasında, siyasi otoritenin olmadığ 1 ve kurulan küçük hanlıkların sürekli çatışma içerisinde olduğu bu dönemde, doğal olarak sanatsal ve edebî faaliyetlerin sekteye uğradığını ve herhangi bir gelişmenin olmadığını söylemek mümkündür. $\mathrm{Bu}$ süreçte yaşamış şairlerin genelinde ise Çağatay Türkçesine klasik halini vermiş olan ve Çağatay Türkçesinin en önemli ismi olarak zikredilen Ali Şir Nevâî'nin etkisinde şiirler kaleme aldıkları, edebî açıdan da onu taklitten öteye gidemedikleri görülmektedir. Ancak Meşreb, eserleri, sıra dişı yaşam tarzı, sûfî kişiliği ve kendine has üslubuyla hem döneminde yaşayan diğer şairlerden ayrılmış hem de asırları aşan bir şöhrete kavuşmuş önemli bir şahsiyettir. "Şah (Îşân) Meşreb Menâkıb-nâmesi" adlı çalışma ise, şairin hayat hikâyesinden kesitleri barındıran manzum-mensur karışık bir eserdir. Mensur kısımlarla birlikte eserdeki şiirlerde de yine bahsi geçen hikâyelerde anlatılan olay örgüsüyle bağlantılı şiirler bulunmaktadır. Söz konusu şiirlerde, din, tasavvuf, tarih, coğrafya, mitoloji gibi birçok konu, şairin muhatabına aktarmak istediği bilgi ve vermek istediği mesajlar doğrultusunda kullanılmıştır. $\mathrm{Bu}$ konulardan biri de şiirlerde yoğun bir şekilde ele alınıp işlendiğini tespit ettiğimiz şahıs kadrosudur. Şahıslardaki bu yoğunluk ve çeşitlilik ise, gerek şairin alana olan hakimiyetini, gerekse bu şahısları şiirlerinde kullanmadaki yeteneğini ve şiirlerdeki anlam derinliğini göstermesi açısından dikkate değer bir bilgi sunmaktadır. Bu çalışmada, Baba Rahîm Meşreb Menâkıb-nâmesi'nde geçen Acem kaynaklı mitolojik şahıslar ele alınıp incelenecektir. Çalışmada, mitolojik şahıslar hakkında verilen genel bilgiler ışığında, şairin bahsi geçen şahısları şiirlerinde nasıl ve ne sıklıkla kullandığı, şiirlerden seçilen örnek metinler ve bu metinlerin açıklamalarıyla birlikte tasnif ve takdim edilecektir.

Anahtar Kelimeler: Çağatay Türkçesi, Sufizm, Baba Rahîm Meşreb, Menâkıbnâme, Mitolojik Şahıslar.

\section{Mythological Characters of Persian Origin in the Poems in Baba Rahim Mashrab Manaqibnama}

\begin{abstract}
Baba Rahim Mashrab is one of the sufi poets who lived in the Post-Classical Period of Chagatai Turkish (1600-1921). In this period, when there was no political authority in the field of Turkestan and the small khanates established were in constant conflict, it is possible to say that naturally artistic and literary activities were interrupted and there was no development. In general, it is seen that the poets
\end{abstract}

Turkish Academic Research Review - Türk Akademik Araştırmalar Dergisi 
who lived in this process wrote poems under the influence of Ali Shir Navai, who gave Chagatai Turkish its classical form and is mentioned as the most important name of Chagatai Turkish, and they could not go beyond imitating him in terms of literature. However, Mashrab is a significant person who both distinguished himself from other poets living in his time and gained a reputation for centuries with his works, extraordinary lifestyle, sufi personality and unique style. "Shah (Îşân) Mashrab Manaqibnama" is a verse-prose mixed work containing sections from the Baba Rahim Mashrab's life story. Along with the prose parts, the poems in the work also contain poems related to the plot told in the aforementioned stories. In the mentioned poems, many subjects such as religion, mysticism, history, geography and mythology were used in line with the information the poet wanted to convey to his addressee and the messages he wanted to give. One of these issues is the staff that we have determined to be handled and processed intensively in the poems. This density and diversity in the characters, on the other hand, provides remarkable information in terms of showing the poet's dominance over the field, his ability to use these people in his poems, and the depth of meaning in the poems. In this study, we will examine the Persian mythological figures mentioned in Baba Rahim Mashrab Manaqibnama. In the study, we will classify and present how and how often the poet uses the mentioned persons in his poems, with sample texts selected from the poems and explanations of these texts, in the light of general information about the mythological persons who will form the subtitles.

KeyWords: Chagatai Turkish, Sufism, Baba Rahim Mashrab, Manaqibnama, Mythological Characters.

\section{Structured Abstract}

Baba Rahim Mashrab, one of the Chagatai Turkish poets of the PostClassical Period according to some researchers, and the Decline or Downfall Period according to other researchers, was born in $1640 \mathrm{AD}$. His real name is Abdurrahim. While he was still in the womb, he started to show miracles and it is realized that he has a superior intelligence and development than other children of his age when he reaches school age, firstly he was sent to Ahund Molla Bazar (Hodja Ubeydullah) (d. 1668), one of the famous scholars of the period, for education. After completing his education there, he went to Hidayetullah Îsân Afak Hodja (d. 1693) for improving himself both scientifically and religiously-sufistic. Abdurrahim improved herself in terms of language and poetry by reading Hafiz (d. 1390) and Mevlana (d. 1273) during his education there. Abdurrahîm, who was given the nickname "Mashrab" by his teacher, started to realize the mistakes and faults of Afak Hodja in the following years and his love and respect for her teacher began to decrease. Even the poet began to claim that he was superior to his teacher. Afak Hodja, who noticed the situation, he expelled Mashrab from the lodge according to one view, Mashrab was in love with one of the concubines in the lodge, and according to another view, with a love slander he put forward. After being expelled from the dervish lodge, Mashrab, who took it as his duty to travel from city to city as a Kalender dervish and enlighten the people on religious-mystical issues, both strengthened the ties between Islam and the people in the places he went, and gained an increasing reputation with the poems he sang. When the subjects he deals with in his poems are examined, Mashrab, which we have determined that he mostly deals with religion and mysticism and works in a didactic style, besides these subjects, history, mythology, sciences of the age (philosophy, logic, medicine, music, sociology...), local materials (holidays, entertainments, wars...), biographical and bibliographic sources also benefited from many sources. The subject of this study is the mythological figures of Persian origin that Baba Rahim Mashrab used in his poems. The study 
includes the determination of which aspects, how often and for what purpose the Persian-origin mythological figures in Mashrab's poems are handled and processed, and analysis with sample couplets and strophes from the poems.

As it is known, "Myth" is the name given to folk tales that can be considered among the types of fairy tales and legends, in which extraordinary events related to the ancient people and their gods are told. There are also studies of many local and foreign scientists on the definition of the concept of myth, its nature and other branches of science, is formed by supporting the extraordinary features of demigods and heroes, which are usually brought to the fore by nations, with extraordinary narratives. However, this study was prepared on the mythological figures of Persian origin in the poems in Baba Rahîm Mashrab's Manaqibnama.

"Manaqib", which is the plural of the Arabic word "Menkabe", can be explained as anecdotes or stories told about historical figures, religious elders, heroes or prominent figures of the people, just like the concept of myth. The works created by bringing these manaqibs together are called "Manaqibnama".

Baba Rahîm Mashrab's extraordinary lifestyle and life stories are brought together in a manaqibnama bearing his name. The aforementioned manaqibnama contains not only the extraordinary life stories of Mashrab, but also the poems written by Mashrab on the subject or sung in the form of attraction. In the aforementioned poems, ten different Persian mythological figures, namely "Behmen - Cem (Jamşid) - Efrasiyab - İsfendiyar - İskender - Keyhüsrev - Keykubad Nûşirevân - Rüstem and Sührâb" have been identified. The poet, who included these identified persons in his poems for a total of thirty-four times, including seventeen couplets, one mustazat and sixteen strophes, highlighted the general characteristics of the individuals conveyed in the narratives (especially in the Shah-nama). These features can be listed under headings such as: bravery and heroism (For example: Efrasiyab, İsfendiyar, Rüstem, Sührâb), justice (Ex.: Keykubad, Nûşirevân), fameglory (Ex.: Behmen, Cem(Cemşîd), Keyhüsrev). In our study, individuals have been conveyed under sub-headings and with general information about them. In the next stage, it is explained with sample couplets that Baba Rahim Mashrab emphasized which aspects of these mythological figures in his poems, how and for what purpose. It is necessary to open a separate parenthesis about Cem (Jamşid) among the persons here. Because Cem, one of the people in question, is mentioned in poems in terms of being an inventor and generally the inventor of wine rather than his fame and glory. However, Cem, whom the sufi poet Mashrab mentions in his poems, the mythological person, wine is not the wine that Cem invented and it is used to describe the divine love in the mystical sense and the state of attraction felt from this love. In addition, it is possible to say that the poet uses mythological figures in his poems for the purpose of praising the person mettioned and himself. The poet, who we stated that he aimed to make the people more conscious about religious issues, also mentioned the names of mythological persons in the couplets and strophes about death and the afterlife. Mashrab stated that even these names, who were known for their bravery and heroism, justice and fame, died and stated that this world is actually a place of testing and the main thing is what kind of life should be lived in this world in order to enter Paradise in the hereafter.

As a result, it is possible to say that the mythological figures of Persian origin, which we have identified in Baba Rahim Mashrab's poems in his Manaqibnama, are used as a tool in line with the subject, event or message that the poet wants to convey to his interlocutor. In addition, we can state that, based on the couplets and strophes mentioned above, Mashrab is not only mastered the religioussufistic sciences but also many branches of science.

Turkish Academic Research Review - Türk Akademik Araştırmalar Dergisi 
938 Baba Rahîm Meşreb Menâkıb-nâmesi’nde Geçen Şiirlerdeki Acem Kaynaklı Mitolojik Şahıslar

\section{Giriş}

Türk edebiyatı, gerek İslamiyet öncesi, gerekse İslamiyet sonrası her dönemde diğer bilim dalları ve kaynaklarıyla etkileşim içerisinde olmuştur. İslâmiyet'in kabulüyle birlikte, sanatkârı ilmî ve fikrî düzeyde besleyen - sanatkâr ve eserleri hakkında bilgi veren bu kaynaklara yenileri de eklenmiştir. Söz konusu yeni kaynaklar arasında Kur'ân-1 Kerîm, hadîsler, kısas-1 enbiyâlar, tasavvuf ve dinî ilimler (kelam, fikıh, İslam felsefesi...) sayılabilir. Dil, tarih, mitoloji, çağın ilimleri (felsefe, mantık, tıp, musiki, sosyoloji...), yerli malzemeler (bayramlar, eğlenceler, savaşlar...) biyografik ve bibliyografik kaynaklara dâhil olan bu yeni kaynaklarla birlikte şairlerin şiirlerinde kullandıkları mazmun ve mefhumların hem nitelik hem de nicelik bakımından arttığını söylemek mümkündür (Detaylı bilgi için bkz.: Kemikli, 2012, ss. 31-35).

Tarihî süreç içerisinde Çin Seddi'nden Balkanlar'a kadar geniş bir coğrafyaya yayılan Türkler, yaşadıkları coğrafyaların sosyo-kültürel yapılarını da kendi inanış ve düşünce sistemiyle yeniden düzenlemişlerdir. Yaşanılan coğrafya farklı olsa da ortak bir tarihe sahip, aynı dine mensup ve farklılıklar olmasına rağmen Türkçe konuşan bu milletlerin sanat faaliyetlerinde de doğal olarak benzerlikler bulunmaktadır. Dolayısıyla Anadolu sahasında şiirler kaleme alan bir şair ile Türkistan ya da Balkanlar'da şiirler kaleme alan bir şairin, -her ne kadar Arap ve Fars edebiyatı tesiri görülse de- benzer kaynaklardan beslenip benzer eserler vücuda getirdikleri aşikârdır.

Bu şairlerin yetiştiği coğrafyalardan biri olan Türkistan’da, Karahanlı ve Harezm Türkçesinden sonra Çağatay Türkçesi dönemi gelir. Temeli Eski Türkçe dönemine kadar indirilebilen Çağatay Türkçesi, XV. yy.da Ali Şir Nevâi ile birlikte klasik halini almış, XVII. yy.dan itibaren gerilemeye başlamış ve XX. yy.da da yerini Özbek Türkçesine bırakmıştır (Ercilasun, 2008, ss. 400-405). Bu tarihî süreçler, dil bilimciler tarafından farklı sınıflandırmalara ayrılmıştır. En çok kabul gören sınıflandırmalar ise Fuad Köprülü ve Janos Eckmann'ınkilerdir. Köprülü, Çağatay Türkçesini şu dönemlere ayırarak sınıflandırmıştır:

1. Erken Dönem Çağatay Türkçesi (13-14.yy),

2. Klasik Öncesi Çağatay Türkçesi (15.yy ilk yarısı),

3. Klasik Dönem Çağatay Türkçesi (15.yy ikinci yarısı),

4. Klasik Çağatay Türkçesinin Devamı (16.yy),

5. Çöküş Dönemi Çağatay Türkçesi (17.-19.yy) (Köprülü, 1945, c. 3, ss. 270323). 
Eckmann'ın ise, Çağatay Türkçesinin en önemli şairi olan Ali Şir Nevâi üzerinden bir tasnif yaptığı görülmektedir:

1. Klasik Öncesi Devir (15.yy - 1465 (Nevâi’nin İlk Divanının Düzenlendiği Y1la Kadar.)

2. Klasik Devir (1465-1600 (Nevâî Dönemi))

3. Klasik Sonrası Devir (1600-1921 (Nevâî Sonrası) (Eckmann, 2017, ss. 1921).

Baba Rahîm Meşreb, Köprülü'nün "Çöküş Dönemi Çağatay Türkçesi”; Eckmann'ın ise "Klasik Sonrası Devir" olarak isimlendirdiği bir dönemde yaşamıştır. Bu dönem, siyasi otoritenin olmadığı ve kurulan hanlıkların sürekli savaş halinde olduğu, dolayısıyla sanatsal açıdan herhangi bir gelişme gösterilemeyip şairlerin Nevâi ve Fuzûlî etkisinde eserler kaleme aldıkları bir dönem olarak ön plana çıkmaktadır (Eckmann, 2003, ss. 208-209).

Çalışmamızın temelini oluşturan kavramlardan biri olan "Mit" ile ilgili ise, yerli ve yabancı bilim insanları tarafından, genel bir tanım yerine çoğunlukla bu kavramın neleri ihtivâ ettiği üzerine yorumların yapıldığı görülmektedir. Konu ile ilgili Nimet Yıldııım, mit kavramının neleri barındırdığını şu şekilde özetlemiştir:

“Eski çağlarda yaşamış insanların doğa olaylarına, sosyal ilişkilere ve dinsel inanışlara bakış açılarının yorumlanışı olarak nitelenen mitolojinin konusu ilkel insanlar ve insanüstü varlıkların başından geçen masalsı olaylardır. Her ulusun mitolojisi o ulusun tarihini, efsanelerini, destanlarını ve kahramanlı öykülerini, tanrlarını ve inanç sistemlerini, masallarını ve söylencelerini barındırır. Mitoloji, hayali bir anlatım içine hayallerde yer etmiş yar tanrlar ve kahramanların hikâyelerini de katan ve ilk çağlara, daha doğrusu arkaik bir zaman türüne, tarihsel zaman ötesindeki başlangıç zamanına dayanan bir öykü anlatım biçimidir (Yıldırım, 2008, s. 11).”

Bunun yanı sıra yabancı bilim insanlarının da mit kavramının tanımı, mahiyeti ve diğer bilim dallarıyla olan bağlantısı ile ilgili farklı yorum ve çalışmalarının olduğunu da söylemek mümkündür (Detaylı bilgi için bkz.: Tökel, 2009, s. 166). Ancak bu çalı̧̧mada Baba Rahîm Meşreb Menâkıb-nâmesi'nde geçen şiirlerdeki Acem kaynaklı mitolojik şahıslar üzerinde durulacaktır. Nitekim mit kavramını bütün yönleriyle ele alıp incelemek daha kapsamlı bir çalışmayı gerektirmektedir.

Turkish Academic Research Review - Türk Akademik Araştırmalar Dergisi 
940 Baba Rahîm Meşreb Menâkıb-nâmesi’nde Geçen Şiirlerdeki Acem Kaynaklı Mitolojik Şahıslar

Arapça "Menkabe" kelimesinin çoğulu olan "Menâkıb" ise, tarihî şahsiyetler, din büyükleri, kahramanlar ya da halk içinde muteber kimselerin yaşayışlarıyla ilgili fikralar ya da hikâyeler olarak özetlenebilir. $\mathrm{Bu}$ menâkıbların derlenip bir araya getirilmesiyle ortaya çıkan dinî-tasavvufî esere ise "Menâkıb-nâme" adı verilir (Detaylı bilgi için bkz.: Pala, 2013, ss. 303-305). Sufi şair Baba Rahîm Meşreb'in de bir menâkıb-nâmesi bulunmaktadır. Bu menâkıb-nâme üzerine, ilerleyen yıllarda farklı ülkelerde birçok araştırmacı tarafından çalışmalar yapılmıştır. Çalışmamızda, bu menâkıb-nâmenin farklı varyantlarında geçen manzumelerdeki Acem kaynaklı mitolojik şahıslar incelenecektir.

Çalışmamızın ilk bölümünde Baba Rahîm Meşreb'in hayatı, kişiliği ve eserleri hakkında genel bilgiler verilecektir. Sonraki aşamada ise Meşreb'in menâkıb-nâmeleri üzerine yapılmış en kapsamlı çalışmalardan Halim Bayat tarafından hazırlanmış olan Külliyât-ı Meşreb Nemengânî; Celâleddin Yusufov tarafindan kaleme alınan Mihribânım Kaydasen ve Mahmut Fidancı 'nın çalışması Şâh Meşreb Menâkıb-nâmesi (Inceleme - Metin - Sözlük) isimli çalışmalarda tespit edilen Acem kaynaklı mitolojik şahıslar, alt başlıklar halinde, haklarında genel bilgilerle sunulacaktır. Verilen genel bilgilerin ışığında ise Meşreb'in şiirlerinde bu şahısların hangi özelliğini ön plana çıkardığı ve kullandığı, örnek beyit ya da bentlerle açıklanarak alt başlıklar sonlandırılacaktır. Sonuç kısmında ise çalışma neticesinde elde edilen bilgiler yorumlanacaktır.

\section{Baba Rahîm Meşreb (M. 1640-1711)}

Asıl adı Abdurrahim'dir. Doğum y1lı ile ilgili M. 1640-1641, 1650, 1653 ve 1657 gibi yıllar zikredilmektedir. Bu yıllar içerisinde en çok kabul gören ise $\mathrm{M}$. 1640 yılıdır (Gedik, 2017, s. 18). Şairin doğum yeri ile ilgili ise iki farklı bilgi bulunmaktadır. Bu bilgilerden ilkine göre Meşreb, Özbekistan'a bağlı Nemengan şehrinde (Meşreb, 1994, s. 5), diğerine göre ise, Nemengan şehrine bağlı Andican (Andukan)'da dünyaya gelmiştir (Kahhar, 2000, c. 15, s. 97; Meşreb, 2015, s. 5). Ancak Meşreb'in şiirlerinde çoğunlukla kendisini Nemenganlı olarak ifade etmesinden ve şiirlerinde Andican ya da Andukan ile ilgili herhangi bir bilgiye rastlamamış olmamızdan hareketle, şairin doğum yerinin Nemengan olması kuvvetli ihtimaldir denilebilir. Konu ile ilgili şu beyitler örnek olarak verilebilir: 
Ne melek-men ne ferişte hem Ādem neslidin

Men tevellüd-i uşel ferzend-i Nemengānimen

(Meşreb, 1994, s. 6; Meşreb, 2004, s. 104)

Nā-resālar sözini mażmūnġa fiḳr etmeġil

Tāze mażmūn isteseñg Meşreb-i Nemengāndın tile

(Bayat, ty., s. 118; Fidanc1, 1994, s. 109)

Ailesi ile ilgili anne, baba ve kız kardeşinin isimlerini tespit edebildiğimiz Meşreb, Molla Veli (Veli Baba) ve Selime (Bibi Selime)'nin oğludur (Gedik, 2017, s. 18; Kanabaev, 2013, s. 7; Kahhar, 2000, c. 15, s. 97). Kız kardeşinin ismi ise Mâh Bedr (Ay Cemâl)'dir (Meşreb, 2015, s. 8). Daha dünyaya gelmeden kerametler göstermeye başlayan Abdurrahim, (Kanabaev, 2013, s. 6; Tolkun, 2001, s. 112) okul çağına geldiğinde de diğer öğrencilerden daha üstün olduğu fark edilince ailesi tarafindan dönemin önde gelen mutasavvıflarından Ahund Molla Bazar (ö. 1668)'ın yanına gönderilmiştir. Molla Bazar'ın rahle-i tedrîsâtında dinî eğitimin yanı sıra Hâfız (ö. 1390) ve Mevlânâ (ö. 1273)'yı da okuyarak kendini geliştirmeye devam eden Abdurrahim, buradaki eğitiminden sonra dönemin bir diğer ünlü âlim ve mutasavviflarından olan Hidâyetullah Îşân Âfak Hoca (ö. 1693)'ya intisab etmiştir (Tacibayeva, 2005, c. 6, s. 338). Âfak Hoca tekkesindeki yedi yıllık müritlik süreci boyunca Arapça ve Farsçayı öğrenen, kendisini dinî-tasavvufî konularda da iyice geliştiren talebesine hocası "Meşreb" mahlasını vermiştir (Fidanc1, 1994, s. 12). Şairin "Meşreb" mahlasını Âfak Hoca'dan aldığıyla ilgili şu beyit örnek olarak verilebilir:

Ḳuddise sırruhū h̦̃ācem Meşreb atımnı ḳoydılar

Kaşgar u Yarkend içide șāḥib-i kibriyā özüm

(Bayat, ty., s. 104; Fidanc1, 1994, s. 97)

Âfak Hoca tekkesinde geçen yedi yıllık müritlik ve eğitim süreci, bazı araştırmacılara göre Meşreb'in tekkedeki cariyelerden birine âşı olması (Tolkun, 2001, s.110; Gedik, 2017, s. 19; Kanabaev, 2013, s. 12; Fidanc1, 1994, s. 12), bazılarına göre ise hocası tarafından üzerine atılan bu aşk iftirası (Meşreb, 2015, ss. 6-10) nedeniyle son bulmuştur. Şair bu ayrıllğı, şiirlerinde şu şekilde kaleme almıştır:

Turkish Academic Research Review - Türk Akademik Araştırmalar Dergisi https://dergipark.org.tr/tr/pub/tarr 
942 Baba Rahîm Meşreb Menâkıb-nâmesi’nde Geçen Şiirlerdeki Acem Kaynaklı Mitolojik Şahıslar

\author{
Yıġlayurmen men garīib tañgla ḳıāmet bolġuça \\ Ol mürüvvetlik ḩāācemdin ayrılıp ḳaldım netey
}

(Bayat, ty., s. 315; Fidanc1, 1994, s. 266)

Tekkeden ayrıldıktan sonra Meşreb, Hoten, Taşkent, Yarkent, Andican, Ürgenç, Hocend, Semerkand, Buhara, Belh, Bedahşan gibi birçok şehre giderek buralarda halkı İslamî ve tasavvufî konularda irşad etmeye çalışmıştır (Tolkun, 2001, s.110; Gedik, 2017, s. 19). Kalender bir derviş olarak y1llar boyu diyar diyar gezen Meşreb, sonunda tekkeye geri dönmüş ve hocası tarafından affedilmiştir. Âfak Hoca Meşreb'e makâmının Hallâc-1 Mansûr'un (ö. 922) makamına eriştiğini söyleyip ölümünün de Belh ve Kunduz vilâyetlerinin valisi Mahmud Bek Katagan tarafından tıpkı Hallâc-1 Mansûr'un ölümü gibi olacağı bilgisini vermiştir. Bu konu şairin şiirlerine de yansımıştır:

Neçe Manșūr öldi irşād-mend muḥabbet yolıda

Mañga hem dārı ḳurulġanda yeter bu ḳısmetim

(Yusufov, 1990, s. 99)

Manṣūr-1 Hallāc dek içtim şarābe'n-țahūr

Çarh urup yığlap turupmen çıḳ̇alı dār aldıg்a

(Bayat, ty., s. 314; Fidanc1, 1994, s. 266; Yusufov, 1990, s. 12)

Dedi pīrim küşendeñg Maḥmūd-1 Belhīi erür Meşreb

Barıp olsam şehīd-i Kerbelā anam riżā bolg̀ıl

(Bayat, ty., s. 156; Fidanc1, 1994, s. 138)

Kanımnı töker ermiş Belḩ şehride Maḥmūd Ḩān

Taḳdīi-i ezel bolsa neyley añga bermey cān

(Bayat, ty., s. 305; Yusufov, 1990, s. 148)

Meşreb'in tekkeden ayrı geçirdiği süreçte hayatta kalan tek büyüğü olan annesini ziyaret ettiği de görülmektedir. Şairin annesine hem yaşadığı süreçleri anlattığı hem de annesini kaybetmesi üzerine duyduğu özlem içerikli şiirlerinden örneklerden bazıları da şunlardır: 
Cemālin̄ng körgeli keldim eyā ey mihribān anam

Meni üçün edā bolġan yüreki tola ḳan anam

(Bayat, ty., s. 151; Fidanc1, 1994, s. 133-134; Yusufov, 1990, s. 71)

Hoten deştini izlep evliyā bolgan balā̋̂g keldi

Köyüp ${ }^{c} 1$ şḳ otığa yanıp edā bolgan balañg keldi

Keçip lezzāt-ı dünyādın içip cām-ı muḥabbetni

Hudānı emrini dep mā-sivā bolgan balañg keldi

(Bayat, ty., s. 153; Fidanc1, 1994, s. 135)

Ey șafā-baḥş-1 bahar (u) būstānım ḳayda sen

Nūr-1 dīdem müşfiḳim ārām-ı cānım ḳayda sen

Yalğuz uylarda refīḳ-i mihribānım ḳayda sen

Ey tiriklig̀ bāi iṣi rūḥ-ı revānım ḳayda sen

Vālidem Mekkem Medīnem mihribānım ḳayda sen

(Bayat, ty., s. 158; Fidanc1, 1994, s. 140; Yusufov, 1990, s. 308)

Aradan geçen yıllarda Meşreb, Orta Asya ve Türkistan'da birçok şehir dolaşmış, gittiği yerlerdeki mutasavvıfların sohbetlerine dâhil olmuş, vefat eden âlim ve mutasavvifların dahi kabirlerini ziyaret ederek onlardan feyz almış ve bulunduğu şehirlerde şiirler söyleyip dinî sohbetler yaparak kendisine yüklediği vazifeyi icra etmeye devam etmiştir. Bu sayede şair, hem dinî-tasavvufî açıdan olgunlaşmış hem de halk arasında çok meşhur bir sûfî-şair olmuştur. Bir gün Belh şehrine giden Meşreb’i dönemin Belh ve Kunduz vilâyetlerinin valisi olan Mahmud Bek Katagan huzuruna davet etmiştir. Davete icâbet eden Meşreb, huzurda yaptığı uygusuz davranış ve ithamlardan dolayı (Fidancı, 1994, s. 23), idam cezasına çarptırılmış ve H. 1123-M. 1711 yılında günümüzde Afganistan sınırları içerisinde bulunan Kunduz şehrinde idam edilmiştir. Türbesi de yine bu şehirdedir. Şairin vefatı ile ilgili Mecmua-i Ebû Tâlib Hâce Fehmî’de şu ifadeler geçmektedir:

"Meşreb der sâl-i 1123 der Kunduz ve fetvâ-i ulemâ ve hükm-i Mahmud Bek Katagan şehîd kerde şode. (Meşreb, 1123 yılında Kunduz'da ulemâ fetvâsı ve Mahmud Bek Katagan'ın hükmüyle şehit edildi.) (Tolkun, 2001, s.111)"

Turkish Academic Research Review - Türk Akademik Araştırmalar Dergisi https://dergipark.org.tr/tr/pub/tarr 
944 Baba Rahîm Meşreb Menâkıb-nâmesi’nde Geçen Şiirlerdeki Acem Kaynaklı Mitolojik Şahıslar

Meşreb'in, Şah (Îşân) Meşreb Menâkab-nâmesi, Mebde-i Nûr, Kimyâ, Hacc-nâme / Şehîd-nâme isimli eserleri bulunmaktadır. Bu eserlerin yanı sira kendisine atfedilen Dîvân, Kıssa-yı Veysü'l-Karânî, Kıssa-yı Mirac-ı Resûl-i Ekrem ve Manzum Fatiha Tefsiri isimli eserleri de zikredilmektedir (Tosun, 2012, s. 443; Gedik, 2017, s. 27; Kanabaev, 2013, s. 23; Baş, 2013, s. 133).

\section{Baba Rahîm Meșreb Menâkıb-Nâmesi’nde Geçen Acem Kaynaklı}

\section{Mitolojik Şahıslar}

Gerek Anadolu sahası ve gerek Orta Asya sahası Türk şiirinde geçen mitolojik şahıslar, çoğunlukla İran menşe'lidir. Bu etkileşimde etkin rolü oynadığı dile getirilen eser ise Şehnâme'dir. Hatta Tanpınar, divan şiirinin mitolojisini doğrudan doğruya Şehnâme'den, büyük masallardan ve Arap kültüründen aldığını ifade etmektedir (Tanpınar, 1985, s. 4). Ancak Türk şiiri mitolojisinin arka planını sadece İran mitolojisi ile sınırlandırmamak gerekir. Çünkü şiirimizde her ne kadar yoğun bir şekilde İran mitolojisi etkisi görülse de Arap, Hint, Çin, Orta Doğu'nun diğer milletleri, Yunan ve Anadolu'da yaşamış diğer milletlerin mitolojisinden izler de bulunmaktadır (Tökel, 2016, ss. 74-75).

Klasik Sonrası Çağatay Türkçesi döneminde, günümüz Özbek Türkçesine yakın bir dil ve kendine has üslûbuyla (Meşrebâne Üslûp) (Meşreb, 2004, s. 3) dinîtasavvufî şiirler kaleme alan Baba Rahîm Meşreb'in şiirlerinde de genellikle İran menşe'li mitolojik şahıslara yer verildiği tespit edilmiştir. Haklarında verilen genel bilgiler ve ön plana çıkan yönleriyle birlikte, Meşreb'in şiirlerinde geçen Acem kaynaklı mitolojik şahıslar şunlardır:

\section{Behmen}

Asıl adı Erdşîr'dir. Bir başka mitolojik şahıs ve İran hükümdarı olan İsfendiyar'ın oğludur (Tökel, 2016, s. 90). Yedi iklime hükmetmeyi kendine amaç edinen Behmen, çok geniş bir coğrafyaya hâkim olmasından dolayı "Dırâzdest" olarak da bilinmektedir (Yıldırım, 2008, ss. 142-144). Edebiyatımızda Behmen, genellikle bu yönleriyle ön plana çıkmış ve övgü amaçlı kullanılmıştır. Meşreb'in şiirlerinde ise Behmen sadece bir beyitte geçmektedir.

Meşreb bu beyitte, kendi hırsını İsfendiyâr ile özdeşleştirirken sabrı ise düşmanı olarak nitelendirmektedir. Ancak şair, çelik bedenli İsfendiyâr gibi olan hırsının karşısında kendisini Behmen’e benzetmektedir: 
İsfendiyār ḥırṣ merā ṣabr-1 düşmen est

Rūyın ț̣n āferīde u Behmen ger āmedem

(Bayat, ty., s. 63; Fidanc1, 1994, s. 59)

\section{Cem - Cemşîd}

Pişdadiyan sülalesinin dördüncü ve en büyük hükümdarıdır (Tökel, 2016, s. 98). Asıl ismi, büyük hükümdar, padişah anlamlarına gelen Cem'dir. Azerbaycan'da, mücevherlerle süslettirdiği tahtını yüksek bir yere koyduran Cem, yine mücevherlerle süslü bir tac giyip tahta oturmuştur. Güneş ışı̆̆ının da tahta vurmasıyla ortaya çıkan parlaklıktan hareketle ismine "Işık" anlamına gelen "Şit" kelimesi de eklenmiştir (Levend, 1984, ss.156-157).

Ahmet Talât Onay, Cem'i sadece şarabın mucidi olarak açıklamıştır. (Onay, 2000, s. 136). Ancak Dursun Ali Tökel, Cem'in şarabın mucidi olması haricinde, demiri yumuşatıp savaş aletleri yaptırdığından, yünlerden ip eğirerek değerli kumaşlar ürettirdiğinden, saraylar inşa ettirdiğinden, kıymetli taşları işlediğinden, güzel kokular icat ettiğinden ve benzeri birçok yeniliği gerçekleştirdiğinden bahsetmektedir (Tökel, 2016, s. 98). Ancak bu yeniliklerden sonra kendisinde boy göstermeye başlayan gurur ve kibir nedeniyle gücünü kaybetmiş ve en sonunda İran’ı terk etmek zorunda kalmıştır.

Birçok icadına ve yeniliklerine rağmen Cem, edebiyatımızda ekseriyetle şarabın mucidi olarak anılmış (Kabaklı, 2011, ss. 409-410) ve ismi "bezm, meclis, sâkî, kadeh, câm..." gibi unsurlarla bir arada kullanılmıştır.

Meşreb'in şiirlerinde Cem (Cemşîd), gazellerde üç, müstezatlarda bir ve muhammeslerde iki kez olmak üzere toplamda altı kez zikredilmiştir. Şair, genel olarak Cem'i şarap ve kadeh mazmunlarıyla birlikte kullanmıştır.

Meşreb'in şiirlerinde Cem, (Her ne kadar gerçek şarabın mucidi de olsa) sûfî şairlerin zikrettikleri ve genellikle tasavvufî manadaki şarapla ilişkilendirilerek kullanılmıştır. Kendisine Hz. Süleymân'ın tahtını dahi verseler, Cem'in şarap dolu kadehiyle değişmeyeceğini dile getiren şair, Hz. Süleymân'ın tahtına oturup ihtişamlı bir hayat sürmek yerine koluna şarap kasesini alıp yoksul ama Allah aşkıyla dolu bir hayatı tercih etmektedir:

Turkish Academic Research Review - Türk Akademik Araştırmalar Dergisi https://dergipark.org.tr/tr/pub/tarr 
946 Baba Rahîm Meşreb Menâkıb-nâmesi’nde Geçen Şiirlerdeki Acem Kaynaklı Mitolojik Şahıslar

Süleymān taḩını Cemşīini cāmığa bermes men

Ḳolumġa kāse-yi çūbīn alıb ḳılg̀an gedālıg̀nı

(Bayat, ty., s. 289; Fidancı, 1994, s. 251; Yusufov, 1990, s. 56)

Bir başka beyitte ise Meşreb, her kim olursa olsun ecel şerbetini bir gün içeceğini ve herkesin bu dünyadan göç edip ebedî âleme gideceğini de "Cemşîd, İskender ve Efrâsiyâb" isimleriyle örneklendirerek vermiştir. Beytin ikinci mısrasında da aynı düşünce farklı bir bakış açısıyla dile getirilmiştir. Bu dünyadaki hiçbir hane, ecel elinden mutluluk bulmamıştır. Hepsi sonunda virane olmuştur:

Kaalmadı Cemşīd İskender (hem) ḳanı Efrāsiyāb

Tapmadı dest-i eceldin hāne-ābād 'āḳıbet

(Yusufov, 1990, s. 211)

\section{Efrâsiyab}

Turan hükümdarı Feridun'un soyundan olan Efrâsiyab, yiğitliği ve kahramanlığıyla ön plana çıkan efsanevi bir şahsiyettir. Firdevsî’nin Şehnâme adlı eserinde “...aslan gibi göğsünü, pazısını, fil gibi kuvvetini, birkaç millik mesafeye kadar uzanan gölgesini // Keskin bir kılıcı andırır gibi dilini, deryâ gibi geniş yüreğini, yă̆murlar yă̆dıran bir bulut kadar cömert elini görmüştü.” (Tökel, 2016, s. 123) şeklinde tasvir ettiği Efrâsiyab, İran'1 ele geçirerek uzun yıllar boyunca burada hüküm sürmüştür. Yıllar boyunca süregelen İran-Turan savaşlarından sonra Keyhüsrev tarafindan öldürülmüştür (Onay, 2000, s. 63).

Meşreb'in şiirlerinde iki farklı yerde geçen Efrâsiyab, bir beyitte ölüm metaforu ile birlikte dünyanın Cemşîd, İskender ve Efrâsiyab gibi yiğit, cesur ve kahraman hükümdarlara bile kalmadığını dile getirmek amacıyla kullanılmıştır. Bir diğer beyitte ise şair, Efrâsiyab'1 Rüstem ile birlikte zikrederek yiğitlik ve cesurluk gibi temaları ön plana çıkarmıştır:

Kalmadı Cemşīd İskender (hem) ḳanı Efrāsiyāb

Tapmadı dest-i eceldin hāne-ābād ${ }^{c} a ̄ k ̣ ı b e t$

(Yusufov, 1990, s. 211) 
Bā Rüstem-i zamāne țaraf geştenem ḩıṭāst

Efrāsiyāb sāz-1 tehemtem ger āmedem

(Bayat, ty., s. 63; Fidanc1, 1994, s. 59)

\section{4. İsfendiyâr}

Lakabı, "Tunç Bedenli" anlamına gelen "R̂̂ŷ̂n-Ten" olan İsfendiyâr, İranlıların bir diğer kahraman hükümdarlarındandır. Gözlerinden başka bedenindeki her yerin adeta demir gibi olduğu ve hiçbir kesici aletin kâr etmediği anlatılmaktadır. Kendisi Rüstem ile girdiği savaşta ölmüştür (Zavotçu, 2013, ss. 388-389).

Meşreb'in şiirlerinde İsfendiyâr'ın ismi bir kez geçmektedir. Şair bu beyitte kendi hırsını İsfendiyâr'a benzetmektedir ve düşmanının ise sabır olduğunu dile getirmektedir. Hırstan kasıt nefistir ve Meşreb kendi nefsinin İsfendiyâr kadar güçlü olduğunu ifade etmeye çalışmıştır. Bu güçlü düşmana karşı ise sabrın en büyük silah olduğunu belirten şair, kendisinin de nefsi kadar güçlü olduğunu belirtmektedir:

İsfendiyār ḥırṣ merā ṣabr-1 düşmen est

Rūyın ṭın āferīde u behmen ger āmedem

(Bayat, ty., s. 63; Fidanc1, 1994, s. 59)

\section{5. İskender}

Bazı kaynaklara göre iki (Levend, 1984, s. 160; Onay, 2000, s. 261) bazı kaynaklara göre ise üç farklı İskender (Tökel, 2016, ss. 147-148) olduğu rivâyet edilmektedir. $\mathrm{Bu}$ İskender'lerden ilki, Makedonya kralı Filip'in oğlu olan İskender'dir. İran’ı baştan başa işgal eden şahıs budur. Edebiyatımızda genellikle İran hükümdarı Dârâ ile yaptığı savaşla anılmaktadır.

İkinci İskender, "Büyük İskender" diye de isimlendirilen, Kur'ân-1 Kerim'de ise “Zülkarneyn” şeklinde geçen (Kehf, 18/83 - 99) kişidir. Peygamber mi yoksa hikmet sahibi biri mi olduğu konusunda farklı yorumlar (Öztürk, 2013, c. 44, s. 565) bulunan İskender, aynı zamanda Hızır ile birlikte âb-1 hayatı bulmaya çalışmasıyla da zikredilmektedir.

Üçüncü İskender ise ilk iki şahsiyetin birbiriyle karıştırılması neticesinde ortaya çıkmış olan İskender'dir. Tarihçiler tarafından birbirine karıştırılan bu iki şahsın ayrıştırılması ise neredeyse imkânsız görülmektedir.

Turkish Academic Research Review - Türk Akademik Araştırmalar Dergisi https://dergipark.org.tr/tr/pub/tarr 
948 Baba Rahîm Meşreb Menâkıb-nâmesi’nde Geçen Şiirlerdeki Acem Kaynaklı Mitolojik Şahıslar

Edebî eserlerde ismi zikredilen İskender ise bazen İskender-i Zülkarneyn, bazen de Makedonyalı İskender olarak her iki karakter şeklinde karşımıza çıkmaktadır.

Meşreb'in şiirlerinde İskender, gazellerde altı ve muhammeslerde yedi kez olmak üzere toplamda on üç kez zikredilmiştir. Şiirlerde her iki İskender de bulunmaktadir.

Aşağıda verilen ilk örnek beyitteki İskender, Hızır ile birlikte âb-1 hayatı bulmaya çalışan, Kur’ân-1 Kerim’de “Zülkarneyn” şeklinde geçen İskender’dir. Ancak şair, bu iki ismi ve âb-1 hayatı burada temsili olarak kullanmaktadır. Meyhânede içtiği şarabı âb-ı hayata benzeten şair, bundan dolayı her dem coşkunluk içinde olduğunu belirtmektedir. Ayrıca şair, seyr-i sülûk yolunda Hızır (a.s) kadar olamasa da Hızır (a.s) ile birlikte o yoldaki İskender gibi olmak istediğini dile getirmektedir:

Dilimde āb-ı ḥayvān cūş uradur otıdın dā'im

Bu yolda Hुıżr eger tapılsa İskender bolay der men

(Bayat, ty., s. 128; Fidanc1, 1994, s. 245)

Meşreb, İskender'i zikrettiği bir bendinde ise dünyanın fânîliği ve hiç kimsenin burada sonsuza dek kalmayacağını muhatabına bildirmektedir. İskender de bu fani dünyadaki devranı bitip bâkî âleme göç eyleyenlerdendir:
Kanı merd-i ḳıyāmet ḩavfıdın ter bolsa müjgānı
Bolur Cennetga dāhil dilde köp bolsa puşeymānı
Ṭarīk-i bendelik düşvār ikendür yoḳdur āsānı
Kạını İskender-i Dānā ḳanı ol şāh-ı sulțānı
Bu fānī dünyādın nevbet-be-nevbet ottı devrānı
(Yusufov, 1990, s. 334)

\section{Keyhüsrev}

Keyhüsrev, Keykâvus ve Efrâsiyab'ın torunu, Siyavuş'un oğludur. Siyavuş, babasının yanından ayrılıp Efrâsiyab'ın yanına sığınmış; Efrâsiyab da kızı Firengis'i Siyavuş’a vermiştir. Bu evlilikten de Keyhüsrev dünyaya gelmiş ve Keykâvus’tan sonra tahta geçip altmış yıl hükümdarlık yapmıştır (Onay, 2000, s. 164). 
Meşreb'in bir bendinde ismi geçen Keyhüsrev de ölüm metaforu ile birlikte zikredilmiştir:

Cehān-ı bī-beḳādur ḳanı Keyhusrev ü Dārāb

Kanı Cemşīi İskender ḳanı ol Rüstem ü Sührāb

Kanı cümle peyamberler ḳanı ol ṣaḥib-i mị̣rāb

Kanı Ṣıddīk ile ${ }^{c}$ Ömer ḳanı ${ }^{\mathrm{C}}$ Oṣman dür-i nā-yāb

Kanı Haydar der erdiler ki men șāḥib- Ḳur’āndur men

(Bayat, ty., s. 8; Fidanc1, 1994, s. 7; Yusufov, 1990, s. 341)

\section{Keykubad}

İran hükümdarlarından Zev'in oğlu Gürşasb'ın otuz yıllık pâdişâhlığı sonrası vefat etmesiyle İran hükümdarsız kalmıştır. Daha sonra İran'ın önde gelenleri Zal'e gidip pâdişâhlığın kime verilmesi gerektiğini sorduklarında Zal, Feridun soyundan gelen Keykubad'ın tahta çıkması gerektiğini belirtmiştir (Tökel, 2016, s. 178). Keyâniyân tahtına oturan Keykubad, yaklaşık yüz yıl boyunca hükümdarlık yapmıştır (Yıldırım, 2008, s. 470). Bu süreç içerisinde Turanlılarla yapılan savaşların ardından Turan hükümdarının barış talebi üzerine savaşları sona erdiren Keykubad, vefat edene kadar ülkesinde barış ve adaletle halkını yönetmiştir.

Edebiyatımızda genellikle adaletiyle ön plana çıkan Keykubad, Meşreb'in şiirlerinde Nûşirevân ve Rüstem ile birlikte sadece bir bentte zikredilmiştir. Meşreb, kendi şanını ve yüceliğini, Keykubad'ın şanı, büyüklüğü ve yüceliğine benzetmiştir:

Kayṣer-i Rūmdın ziyad taht ile devletim meni

Nūşirevān u Keykūbād şān ile şevketim meni

Rüstem-i dāstān erür küç ile ḳuvvetim meni

Küfr ü ỉmānġa yoḳtur u heç kimse nisbetim meni

Hem vațanım șanem meni hem şeh ü hem gedā özüm

(Fidanc1, 1994, s. 96)

\section{Nûşirevân}

İran’ın Sasani sülalesinden olan Nûşirevân, M.S. 531-539 yıllarında hükümdarlık yapan, adaletiyle ön plana çıkan bir diğer hükümdardır (Tökel, 2016, s. 190). İran hükümdarları için kullanılan bir unvan olan“Kisrâ”nın ilk defa verildiği

Turkish Academic Research Review - Türk Akademik Araştırmalar Dergisi https://dergipark.org.tr/tr/pub/tarr 
950 Baba Rahîm Meşreb Menâkıb-nâmesi’nde Geçen Şiirlerdeki Acem Kaynaklı Mitolojik Şahıslar

şahıs olarak da ön plana çıkan Nûşirevân, sarayının balkonuna zencir-i adl (adalet zinciri) adıyla bilinen bir çan astırması ve sorun yaşayanların bu çanı çalması durumunda onların sıkıntılarını gidermesiyle de anlatılmaktadır. Nûşirevân'ın "Eyvân-1 Kisrâ" olarak bilinen sarayının da Hz. Muhammed (s.a.v.)'in doğduğu gece yıkıldığı rivâyet edilmektedir. (Onay, 1992, s. 404; Yıldırım, 2008, ss. 558559).

Edebiyatımızda Nûşirevân, adaleti ve yaptırdığı sarayları ile ön plana çıkmıştır. Meşreb'in şiirlerinde ise Nûşirevân, sadece bir bentte geçmektedir. Söz konusu bentte şair, kendi şanı ve yüceliğinin Nûşirevân ve Keykubad'ın şanı ve yüceliğiyle benzer seviyede olduğunu dile getirmektedir:

Kayṣer-i Rūmdın ziyad tah̆t ile devletim meni

Nūşirevān u Keykūbād şān ile şevketim meni

Rüstem-i dāstān erür küç ile ḳuvvetim meni

Küfr ü ỉmānġa yoḳtur u heç kimse nisbetim meni

Hem vaṭanım ṣanem meni hem şeh ü hem gedā özüm

(Fidanc1, 1994, s. 96)

\section{Rüstem}

Rüstem-i Zâl, Pûr-1 Zâl, Rüstem-i Dâstân, Heft-hân-1 Acem (Levend, 1984, s. 166) gibi farklı isimlerle karşımıza çıkan Rüstem, başta kahramanlık olmak üzere, güç, kuvvet ve yenilmezliğin sembolüdür (Pala, 2013, s. 382). M.Ö. IV. yy. da yaşadığı tahmin edilen Rüstem hakkında birçok menkıbe anlatılmaktadır (Tökel, 2016, ss. 194-202).

Meşreb'in şiirlerinde Rüstem, gazellerde ve muhammeslerde üçer kez olmak üzere toplamda altı kez zikredilmiştir. Şiirlerde şair, genel olarak Rüstem'in yiğitliği ve kahramanlığı üzerinde durmuştur. Beyit ve bentlerde, Rüstem ile birlikte yiğitlik ve kahramanlıklarıyla ün salan diğer şahsiyetlerin de isimleri geçmektedir.

Şair, memleketinden kendisini ziyarete gelen dostlarını görünce onları methetmek amacıyla bir gazel söylemiştir. Bu gazelde ise dostlarını tasvir ederken yiğitlik ve cesurluk konusunda onları Rüstem ve oğlu Sührâb'a benzetmiştir. Şair beytin ikinci mısrasında ise dostlarını adalet tahtına oturmuş sultanlar olarak nitelendirmiştir: 
Şecācat bābıda her ḳaysısı bir Rüstem (ü) Sührāb

${ }^{c}$ Adālet tahtığa mingen bu kün sulțānlarım keldi

(Bayat, ty., s. 225; Fidanc1, 1994, s. 195; Yusufov, 1990, s. 52)

Bir bendinde ise Meşreb, kendi vasıflarını aktarırken tarihî ve efsanevî şahısları kullanmıştır. Kendisini, Rum hükümdarının devletinden daha yüce bir devlete sahip biri olarak ifade edip, şan ve şöhretinin ise Selçuklu Devleti'nin en ünlü sultanı Alâeddîn Keykûbat'tan daha fazla olduğunu belirtmiştir. Bendin devamında, kendi gücünü Rüstem'in güç ve kuvvetiyle ilişkilendiren şair, küfür ve îman konusunda ise kendisiyle mukayese edilebilecek hiç kimsenin olmadığını belirtmektedir. Vatanının, put gibi güzel olan sevgilinin yanı olduğunu söyleyen Meşreb, sevgilinin yanında ise kendisini hem şah hem de kul, köle olarak tasvir etmektedir:

Kayṣer-i Rūmdın ziyad tah̆t ile devletim meni

Nūşirevān u Keykūbād şān ile şevketim meni

Rüstem-i dāstān erür küç ile ḳuvvetim meni

Küfr ü ỉmānġa yoḳtur u heç kimse nisbetim meni

Hem vațanım ṣanem meni hem şeh ü hem gedā özüm

(Fidanc1, 1994, s. 96)

\section{Sührab}

Rüstem'in Semengân ülkesi hükümdarının kızı olan Tehmine'den dünyaya gelen oğludur. Babası Semengân'dan ayrılınca annesi ile birlikte büyümüş ve tıpkı babası gibi cesur ve kahraman bir yiğit olmuştur. Ancak kader, bu iki yiğit ve kahraman baba-oğulu bir savaş meydanında karşı karşıya getirir ve Rüstem oğlunu öldürür. O sırada kendi oğlu olduğunu anlasa da artık iş işten geçmiştir (Levend, 1984, s. 167; Tökel, 2016, ss. 207-208).

Edebiyatımızda Sührâb da tıpkı babası gibi kahramanlıklarıyla ön plana çıkmış bir mitolojik şahsiyettir. Meşreb'in şiirlerinde Sührab, iki farklı yerde ve babasıyla birlikte zikredilmiştir.

Rüstem'in de isminin yer aldığı, örnek olarak verilen aşağıdaki bentte şair, bu dünyanın gelip geçici olduğunu, bâkî olanın ise âhiret hayatı olduğunu ifade etmektedir. Bu amaçla da peygamberlerden, hulefâ-yi râşidînden, tarihî, efsanevî ve

Turkish Academic Research Review - Türk Akademik Araştırmalar Dergisi 
952 Baba Rahîm Meşreb Menâkıb-nâmesi’nde Geçen Şiirlerdeki Acem Kaynaklı Mitolojik Şahıslar

mitolojik şahsiyetlerden birçok örnek isim vererek hepsinin bu dünyadan bâkî âleme göç eylediklerini söylemektedir. Bunu dile getirirken de muhatabına bahsi geçen isimlerin nerede olduklarını sorarak anlatımda istifham sanatına yer vermektedir:

Cehān-ı bī-beḳādur ḳanı Keyhusrev ü Dārāb

Kanı Cemşīd İskender ḳanı ol Rüstem ü Sührāb

Kanı cümle peyamberler ḳanı ol șaḥib-i mị̣rāb

Kanı Șıddīḳ ile ${ }^{c}$ Ömer ḳanı ${ }^{\mathrm{C}}$ Oṣman dür-i nā-yāb

Kạını Haydar der erdiler ki men șāḥib-Ḳur’āndur men

(Bayat, ty., s. 8; Fidanc1, 1994, s. 7; Yusufov, 1990, s. 341)

\section{Sonuç}

Klasik Sonrası Çağatay Türkçesi dönemi sûfî şairlerinden Baba Rahîm Meşreb'in menâkıb-nâmesi'nde geçen şiirlerinde, toplamda on farklı Acem kaynaklı mitolojik şahıs tespit edilmiştir. Tespit edilen mitolojik şahıslara on yedi beyit, bir müstezat ve on altı bent olmak üzere toplamda otuz dört kez şiirlerinde yer veren şair, şahısları Şehnâme'de geçen özellikleri dâhilinde kullanmıştır.

Bunun yanı sıra Meşreb, benzer özellikleri bulunan mitolojik şahısları beyit ya da bentlerde bir arada zikretmektedir. Şahıslar, genellikle adalet, yiğitlik, cesurluk, kahramanlık gibi konularla birlikte ele alınıp işlenmiştir. Ayrıca Meşreb'in, mitolojik şahıslarla birlikte peygamberleri, hulefâ-yi râşidîni, tarihî ve efsanevî şahısları da şiirlerine dahil ettiği görülmüştür. Şair, hepsinin bu dünyadan göç edip gittiklerini belirtip muhatabına bu dünyanın faniliğini de hatırlatmaktadır. Şairin Acem kaynaklı mitolojik şahısları, memdûhun övgüsü amacıyla kullanmasının yanı sıra şahsını övmek için kullandığı da tespit edilmiştir. Kendi şanını ve yüceliğini de şair, mitolojik şahısların şanı ve yüceliğiyle bir tutmuştur.

Son olarak Meşreb'in, gerek şiirlerinde tespit edilen mitolojik şahısları kullanmadaki mahareti ve gerekse diğer bilim dallarına olan hakimiyetiyle, hem ilmî-edebî, hem de dinî-tasavvufî yönden kendisini iyi derecede geliştirmiş önemli bir şahsiyet olduğu söylenebilir. 


\section{Kaynakça}

Baş, Münire Kevser (2013), “Son Dönem Çağatay Şairi Baba Rahim Meşreb’in Manzum Fâtiha Tefsiri”, Toplum Bilimleri Dergisi, (S. 13, ss. 131-156).

Bayat, Halim (t.y.), Külliyât-ı Meşreb Nemengânî, Peşaver: Tac Mahal Yayınları.

Eckmann, Janos (2017), Çă̆atayca El Kitabı, çev.: Günay Karaağaç, Ankara: TDK Yayınları.

Ercilasun, Ahmet B. (2008), Başlangıçtan Yirminci Yüzyıla Türk Dili Tarihi, Ankara: Akçă̆ Yayınları.

Fidancı, Mahmut (1994), Şah Meşreb Menâkıb-nâmesi, Yayımlanmamış Doktora Tezi, İstanbul Üniversitesi, İstanbul.

Gedik, Sadi (2017), Meşreb (Baba RAHÎM) Mebde-yi Nûr, Ankara: TDK Yayınları.

Kahhar, Tahir (2000), "Babarahim Meşreb”, Türkiye Dışındaki Türk Edebiyatları Antolojisi, Ankara: T.C. Kültür ve Turizm Bak. Yayınları, (c. 15. s. 97).

Kemikli, Bilal (2012), Türk İslâm Edebiyatı Giriş, Bursa: Emin Yayınları.

Kur'an Yolu Türkçe Meal ve Tefsir (2012), haz.: Hayrettin Karaman vd., Ankara: Diyanet İşleri Başkanlığı Yayınları, (c. I-V).

Levend, Agâh Sırrı (1984), Divan Edebiyatı (Kelimeler ve Remizler, Mazmunlar ve Mefhumlar), İstanbul: Enderun Kitabevi Yayınları.

Meşreb, Baba Rahim (1994), Mebde-i Nûr, haz.: Haci İsmetullah Abdullah, Taşkent: Özbekistan Respublikası Fenler Akademiyası Fen Neşriyatı Yayınları.

(2004), Dilim Deryâ-i Nurdur, haz.: Abdureşid Abdugafurov, Taşkent: Gafur Gulam Namıdagi Neşriyat.

(2015), Mebde-i Nur, haz.: Kâzım Âmini, Kabil: El Ezher İntişaratı Müessesesi Yayınları.

Onay, Ahmet Talât (1992), Eski Türk Edebiyatında Mazmunlar, haz.: Cemal Kurnaz, Ankara: DİB Yayınları.

(2000), Eski Türk Edebiyatında Mazmunlar ve İahı, Ankara: Akçă̆ Yayınlar1.

Öztürk, Mustafa (2013), “Zülkarneyn”, DİA, İstanbul: TDV Yayınları, (c. 44, ss. 564-567).

Pala, İskender (2013), Ansiklopedik Divan Şiiri Sözlüğü, İstanbul: Kapı Yayınları.

Tacibayeva, M. (2005), "Meşreb", Türk Dünyası Edebiyatçıları Ansiklopedisi, Ankara: AKM Başkanlığı Yayınları, (c. I-VIII).

Tanpınar, Ahmet Hamdi (1985), 19 uncu Asır Türk Edebiyatı Tarihi, İstanbul: Çağlayan Kitabevi Yayınları.

Turkish Academic Research Review - Türk Akademik Araştırmalar Dergisi https://dergipark.org.tr/tr/pub/tarr 
954 Baba Rahîm Meşreb Menâkıb-nâmesi’nde Geçen Şiirlerdeki Acem Kaynaklı Mitolojik Şahıslar

Tolkun, Selahittin (2001), "Meşreb”; Türk Kültürü Dergisi, (S. 454, ss. 110-115).

Tosun, Necdet (2012), "Çağatayca Yazılmış Menâkıpnâmeler", İslâmî Türk Edebiyatı Sempozyumu, İstanbul: Sütun Yayınları, (ss. 437-454).

Tökel, Dursun Ali (2016), Divan Şiirinde Şahıslar Mitolojisi, İstanbul: FSM Vakıf Üniversitesi Yayınları.

(Ocak-Nisan 2009), "Kutsal Metinleri Anlamada Mitolojinin Rolü”, Milel ve Nihal (İnanç, Kültür ve Mitoloji Araştırmaları Dergisi), (c. 6, S. 1,. ss. 165-193).

Yıldırım, Nimet (2008), Fars Mitolojisi Sözlüğü, İstanbul: Kabalcı Yayınları.

Yusufov , Celaleddin (1990), Baba Rahim Meşreb - Mihribânım Kaydasen, Taşkent: Gafur Gulam Namıdagi Neşriyat.

Zavotçu, Gencay (2013), Klasik Türk Edebiyatı Sözlüğü (Kişiler - Hayvanlar Bitkiler - Tabîat Güçleri Kişileştirilmiş Varlık ve Kavramlar), İstanbul: Kesit Yayınları. 